Aim of the study: The aim of the study was to determine the psychological factors that will help reduce the level of stress in people supporting leukaemia patients.

Material and methods: The study group consisted of 100 close relatives supporting leukaemia patients ( 66 women and 34 men). The study included close relatives who supported patients with the diagnosis of leukaemia. A standardized interview and the questionnaires CISS, SES, SOC-29, STAI, and the Questionnaire of Perceived Control of Life were used in the study.

Results: The research results show that $65 \%$ of the respondents indicate the illness of a close relative as the main source of stress. Among the respondents, the emotion-oriented style ( $\beta=0.301, p=0.008)$ and anxious personality ( $\beta=0.560, p=0.000)$ proved to be predictors of stress. Stress is counteracted by a sense of coherence $(\beta=-0.294, p=0.028)$.

Conclusions: In respect of struggling with stress by people supporting leukaemia patients, releasing accumulated tension and formulating negative emotions are the key issues. The strengthening of the sense of coherence will also be crucial.

Key words: stress, anxiety, relatives, leukaemia.

Contemp Oncol (Pozn) 2019; 23 (2): 110-114 DOI:https://doi.org/10.5114/wo.2019.85883

\section{Predictors of stress in close relatives supporting patients with leukaemia}

\author{
Anna Kaczmarska-Tabor ${ }^{2}$, Helena Wrona-Polańska ${ }^{1}$
}

1Department of Applied Psychology, Institute of Educational Sciences, Pedagogical University of Cracow, Poland

${ }^{2}$ Institute of Social Sciences, University of Economy, Bydgoszcz, Poland

\section{Introduction}

The illness of a family member significantly affects other close relatives and family values. The family is defined as a network of mutual interactions among its members [1]. Cancer significantly disturbs the functioning of the family system, sometimes leading to a severe crisis [2]. The study results indicate that caregivers of cancer patients are more likely to have higher levels of anxiety and anger and more often suffer from sleep disorders compared to those supporting AIDS and dementia patients [3]. Chronic stress and passive coping with it lead to the accumulation of negative emotions, and an excessive level of cortisol is released into the blood. This may lead to hyperadaptosis, and consequently, depending on the vegetative response pattern, to the disease [4].

The disease occurring in the family can directly affect the mental state of close relatives or indirectly disorganize important values resulting from relations such as intimacy, support or experience sharing [5].

As a result of cancer-related stress, patients may experience the so-called state of "pendency" and family life dysfunction may occur. The patient stops making long-term decisions and achieving goals, and it is difficult for them to actively participate in family life. Patients suffer from excessive concentration on health issues and anxiety related to relapse. Such an anxious attitude of the patient and their family leads to the creation of a destructive vicious circle and prevents returning to balance [6]. Due to illness, communication between family members is often disturbed. The most common reason is the suppression of emotions by a person who supports the patient. As a result, the behaviour of a caregiver towards family and medical staff can be impulsive and conflictual [7]. The disease can also have a positive effect on the family relations. On numerous occasions, even in moments of crisis, it leads to deepening and strengthening of family bonds [8].

Usually, at the beginning of the disease, people who support the patient are characterized by acceptance and mobilization to action; impatience arises with time. The states of mobilization and exhaustion may alternate. Most frequently, lability is associated with a feeling of guilt of not being good enough as a caregiver [6].

Relatives often feel helpless and confused. A lack of ability and possibility to recognise the patient's needs; tiredness, a need for rest and pleasure can be a source of inner conflict, which in turn leads to the occurrence of burnout among caregivers. This conflict is usually connected with a feeling of guilt that they are healthy and/or that they are not good enough as caregivers [9]. People exposed to long-term stress experienced with regard to work, illness or taking care of a child with disability are prone to greater susceptibility to depression, cardiovascular disease, digestive system disease, hypertension, and autoimmune diseases [10]. The results of research conducted among women taking care of chronically ill children show that 
the high level of stress experienced by them is reflected in telomere length and telomerase level [11]. Chronic stress may translate into a shorter life and may be linked to the onset of oncological and cardiovascular diseases [12].

Currently, in psychology, stress is most often recognized in terms of relations. In the classic approach of R. Lazarus and S. Folkman, the authors of the cognitive-transactional concept of stress define stress as: "a particular relationship between the person and the environment, that is appraised by the person as taxing or exceeding his or her resources and endangering his or her well-being" [13] The key issue in this relationship is the significance that the individual gives to a currently experienced situation. Subjective cognitive appraisal is essential in the process of classifying a given experience as stress. The appraisal made by the person determines whether the transaction is considered to be a stressor. The cognitive appraisal process consists of primary appraisal and secondary appraisal. The primary appraisal regards the assessment of the requirements imposed by the environment, and the secondary appraisal regards the assessment of the person's own ability to cope in a given situation [14].

The primary appraisal of the transaction includes an assessment from the perspective of significance for the person and can be defined as: irrelevant, positive/beneficial, stressful. Classifying a situation as stressful means recognizing it as: harm/loss, threats or challenges [15]. According to Lazarus, although the appraisals of loss and danger are separate concepts, the event can be categorized simultaneously in both categories. Over time, the dominance of one appraisal may change over another [16]. Primary and secondary cognitive appraisals are believed to be dynamic processes that are closely interrelated [17].

There is also a reappraisal, which is carried out after the primary and secondary appraisal. The assessment of the event as a threat persists until the person sees the possibility of changes in themselves or in the environment. The reappraisal occurs when the person starts the process of coping with the stressful situation $[15,16]$.

The transactional definition of stress was complemented by Folkman with the role of positive emotions. Folkman and Moskowitz associate positive emotions with searching and giving a positive meaning to the event [18]. Therefore, coping can mean: giving ordinary events a positive meaning, strengthening positive affect, finding benefits in stressful events [19]. Positive emotions play a significant role in health outcomes. The ability to elicit and experience them is a kind of internal self-therapy [20]. In a difficult situation, positive affect protects against depression. The ability to experience gratitude, love and interest, even in a crisis, can lead to an increase in the individual's resources [21]. Hobfoll associates stress with certain conditions: "1) the threat of a loss of resources or 2) the actual loss of resources an individual, anchored in a family which is anchored in a social organisation, needs to survive. Moreover, since people invest their valued goods in the hope of greater profit, stress can also predict 3) when the investment of resources does not bring the expected profit to the individual or their social group, which is tantamount to a loss" [22]. Resources include objects valued by the individual, circumstances, personality traits and energy potential that enable existence or are needed to acquire the resources needed for existence. Hobfoll, in the theory of stress called environmental, takes into account history, cultural anthropology, evolution and human culture. In his opinion, stress occurs in the situation of particular objective conditions regarding resource management, i.e. disruption of homeostasis in the scope of resource exchange between the individual and the environment [23].

According to Wrona-Polańska [17, 24], stress is the reverse of health. Stress, defined in that way, means an imbalance between the requirements and the capabilities of the individual. Requirements are considered at the internal and external level, while capabilities are the subjective and social resources that people have at their disposal. According to the above concept, not stress itself but negative affect as a result of experienced stress and ineffective coping with it is the risk factor for disease.

In respect of stress issues, the crucial point is stress coping. Coping focused on emotions and the problem can occur in various forms. The aim of coping is either to change the situation, eliminate the cause of the difficulty, or improve the emotional state, or eliminate difficult emotions such as sadness or anger resulting from experiencing the stressor. According to Lazarus, coping methods are applied by the person on conscious and unconscious levels. Therefore, it is seen as a continuum, where healthy and maladaptive ways of coping and activities are borderline [16].

Effective coping with stress includes both the control of emotions and actions taken by the person to change the situation into a more favourable one [25].

\section{Material and methods}

The aim of the research was to determine psychological factors that will help reduce the level of stress among people supporting patients with leukaemia in the situation of numerous stressors associated with the disease of a close relative. At the same time, they will favour the adaptation to change and reduction of psychological costs associated with assisting the patient. Research was carried out as part of the doctoral thesis of Anna Kaczmarska-Tabor.

The Functional Health Model developed by Wrona-Polańska [17, 24] was adopted as the theoretical basis. According to the above model, "health is a function of creative coping with stress by mobilizing resources; and effective strategies from the point of view of well-being are: problem solving, positive reappraisal, seeking support and not focusing on emotions" [24, p. 143]. Creative coping with stress means applying adapted and flexible coping methods for solving the problem, where the individual's resources play the main role. In accordance with the Functional Health Model, a pro-health personality and its components, i.e. cognitive resources such as a sense of coherence, self-esteem, and a sense of control, are crucial for well-being. The resources affect well-being in direct and indirect ways [17, 24].

The study group consisted of 100 close relatives supporting patients with leukaemia from the Chair of Hae- 
matology Clinic of the Jagiellonian University Collegium Medicum and the charges of the Urszula Smok "Podaruj życie" Foundation. The research group consisted of 66 women and 34 men. The study included close relatives who supported patients with a diagnosis of leukaemia. The average age in the research group was 47 years with a standard deviation of 13.58. The time indicator for assisting a close relative was on average 2 years and 8 months. Predominantly, the respondents supported a spouse (37 people) or a parent (30 people).

The collected material has been developed in a quantitative and qualitative manner. The research primarily focused on obtaining information on factors conducive to effective coping with stress. For this purpose, linear regression analysis was performed.

The study included: a standardized interview constructed on the basis of the Questionnaire of Stressful Life Events by Wrona-Polańska [17] to study health, stress and a sense of support from others and self-efficacy in coping with the illness of a close relative, the Coping Inventory for Stressful Situations Questionnaire (CISS) by Endler and Parker, in the adaptation of Strelau, Jaworowska, Wrześniewski, Szczepaniak; The Rosenberg Self-esteem Scale (SES) by Rosenberg; the Orientation to Life Questionnaire (SOC-29) by Antonovsky; State Inventory and Anxiety Traits (STAI)) by Spilberger, Strelau, Tysarczyk and Wrześniewski; and the Perceived Control of Life Questionnaire by Bryant.

\section{Results}

The scale X-1 of the STAI Questionnaire was used to study the stress level of people supporting patients with leukaemia (the scale was used to examine anxiety as a state). The average result was 6.9 sten scores. This result

Table 1. Results distribution for the X-1 variable (anxiety as a state) - sten scores

\begin{tabular}{|lcc|}
\hline Level of result & Sten scores & $\begin{array}{c}\text { Percentage } \\
\text { of respondents }\end{array}$ \\
\hline Low & $1-4$ & 7 \\
Average & $5-6$ & 41 \\
High & $7-10$ & 52 \\
\hline
\end{tabular}

indicates an increased level of stress among the respondents.

Table 1 illustrates the result distribution of anxiety as a state (understood as a stress indicator) among the respondents. For more than half of the participants in the study, the result was high.

Analysis of casual utterances of the respondents revealed that the main source of stress for people supporting leukaemia patients were:

- illness of a close relative $-65 \%$,

- anxiety about the deterioration of the health of a close relative $-52 \%$,

- financial difficulties - 49\%,

- overburden with family and professional duties - 47\%,

- health problems - 41\%,

- no time for yourself - 37\%.

For the respondents, a close relative's illness and anxiety related to the possibility of deterioration of their health are the main stressors. A sense of excess household as well as professional duties, financial difficulties and health problems of people supporting leukaemia patients are also sources of stress. Overburden with duties can lead to caregiver stress syndrome, also known as burnout. The disease of a close relative, including cancer, is usually perceived as a chronic stress-inducing factor. People who support the patients often experience negative psychological, physical and behavioural effects resulting from caring. On numerous occasions, they face a situation when they have to make a decision between competing priorities. The state of chronic tension may lead to the dysfunction of the immune and autonomic systems. In the group of risk there are the caregivers of people suffering from hematopoietic cancers because the course of these diseases is often intense and unpredictable [26].

In order to determine the predictors of stress, a regression analysis for the stress level of people supporting leukaemia patients was conducted with respect to coping styles (Table 2).

Among the respondents the emotion-oriented style proved to be a predictor of stress $(\beta=0.301, p=0.008)$. The higher the predisposition to cope with the stress situation by focusing on emotions, the higher was the level of stress.

Table 2. Summary of linear regression for styles of coping with stress as stress predictors

\begin{tabular}{|c|c|c|c|c|c|}
\hline \multirow[t]{2}{*}{ Style of coping with stress } & \multicolumn{2}{|c|}{ Unstandardized coefficients } & \multirow{2}{*}{$\begin{array}{c}\text { Standardized } \\
\text { coefficients } \\
\beta\end{array}$} & \multirow[t]{2}{*}{$t$} & \multirow[t]{2}{*}{ Significance } \\
\hline & B & $\begin{array}{c}\text { Standard } \\
\text { error }\end{array}$ & & & \\
\hline (Constant) & 47.177 & 9.195 & & 5.131 & 0.000 \\
\hline Task-oriented style & -0.112 & 0.122 & -0.112 & -0.919 & 0.361 \\
\hline Emotion-oriented style & 0.276 & 0.101 & 0.301 & 2.727 & 0.008 \\
\hline Avoidance style & -0.336 & 0.265 & -0.324 & -1.267 & 0.209 \\
\hline Getting engaged in substitutive activities & 0.270 & 0.359 & 0.143 & 0.751 & 0.455 \\
\hline Searching for social contact & 0.197 & 0.451 & 0.081 & 0.438 & 0.663 \\
\hline
\end{tabular}

$R=0.380, R^{2}=0.145$, adjusted $R^{2}=0.095, F(5.86)=2.909, p<0.018$, standard error of the estimate: 8.366 
Table 3. Summary of linear regression for subjective resources as stress predictors in people supporting leukaemia patients

\begin{tabular}{|c|c|c|c|c|c|}
\hline \multirow[t]{2}{*}{ Stress predictors } & \multicolumn{2}{|c|}{ Unstandardized coefficients } & \multirow{2}{*}{$\begin{array}{c}\text { Standardized } \\
\text { coefficients } \\
\beta\end{array}$} & \multirow[t]{2}{*}{$t$} & \multirow[t]{2}{*}{ Significance } \\
\hline & B & Standard error & & & \\
\hline (Constant) & 24.497 & 13.016 & & 1.882 & 0.063 \\
\hline A sense of coherence & -0.129 & 0.058 & -0.294 & -2.226 & 0.028 \\
\hline Self-esteem & 0.294 & 0.237 & 0.149 & 1.241 & 0.218 \\
\hline General sense of control & 0.066 & 0.144 & 0.054 & 0.457 & 0.649 \\
\hline Anxious personality & 0.631 & 0.132 & 0.560 & 4.766 & 0.000 \\
\hline $\begin{array}{l}\text { A sense of effectiveness in dealing with the disease of } \\
\text { a close relative }\end{array}$ & -0.390 & 0.286 & -0.124 & -1.349 & 0.181 \\
\hline A sense of support from others & 0.373 & 0.299 & 0.112 & 1.248 & 0.215 \\
\hline
\end{tabular}

$R=0.663, R^{2}=0.440$, adjusted $R^{2}=0.403, F(6.90)=11.780, p<0.000$, standard error of the estimate: 7.419

The set of variables introduced to the model explains about $15 \%$ of the variance of the variable stress level $\left(R^{2}=\right.$ $0.145)$. The model is adapted to $F$ variables $(5.86)=2.909$, $p<0.018$.

The obtained results (Table 3 ) indicate that, among the respondents, anxious personality is a predictor of stress $(\beta=0.560, p=0.000)$. The higher the personality disposition to experience anxiety, the higher the level of stress. Stress is counteracted by a sense of coherence $(\beta=-0.294$, $p=0.028)$. The obtained result means that a higher level of sense of coherence and a lower level of dispositional anxiety are conducive to lowering the level of stress among people supporting patients with leukaemia.

\section{Discussion}

In the discussed issue, following Wrona-Polanska [17], the key significance for well-being was assigned to cognitive resources (i.e. a sense of coherence, a sense of control, self-appraisal, a feeling of support, self-efficacy and low level of dispositional anxiety). Resources prove to be particularly important in a difficult situation when an individual makes an effort to find resources that will be useful in solving the problem [22, 27].

More than half of the respondents obtained high or average results on the scale to measure anxiety as a state (STAI X-1 Questionnaire). In the research it was assumed that it is a stress level indicator. The disease of a close relative is the main source of stress for the respondents. The results of research conducted among parents of children with cancer indicate that the diagnosis, treatment, anxiety related to recovery, other patients' death, financial and workplace difficulties, and strong emotions of the caregiver and other family members have a significant trauma effect [28].

The conducted regression analysis revealed that the emotion-oriented style is an important positive predictor of stress. Concentration on negative emotions such as anger or guilt and/or predisposition to wishful thinking consequently leads to growing tension, which endangers well-being.

Anxious personality (considered in terms of deficit) proved to be a predictor of stress. Anxious personality is

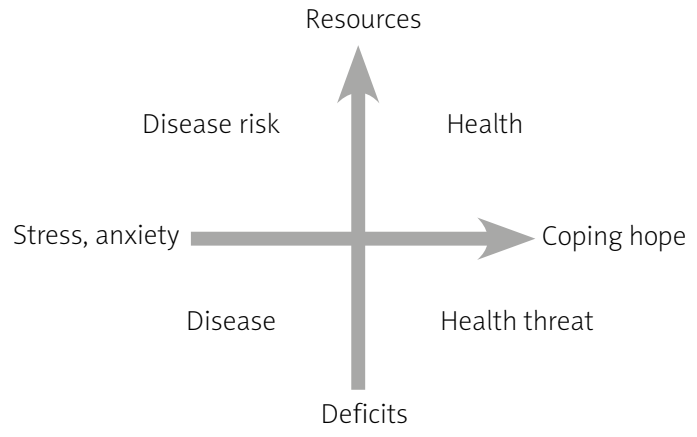

Fig. 1. Functional Model of Health and Disease [24]

understood as a personality predisposition to perceiving life events as threatening.

Regression analysis revealed that stress is counteracted by a sense of coherence.

Antonovsky used the concept of sense of coherence to describe the properties of a person who stays healthy, even in an extremely difficult psychological situation [29]. The results of the conducted research are in accordance with the literature, which indicate that a strong sense of coherence is negatively linked to stress, depression, anxiety or depressed mood [30]. People with a strong sense of coherence are characterized by a tendency to assess stressful events as less aggravating and perceive them as challenges [31].

\section{Conclusions}

Williams [32], based on research carried out among the caregivers of people with bone marrow transplantation, distinguished potential sources of their support such as an ability to provide insight, engagement, taking care of themselves, contact with other people, role negotiation, and expectation management.

Based on the conducted research results, in respect of struggling with stress by people supporting leukaemia patients, an ability to release accumulated tension and negative emotions seems to be vital. It will also be crucial to strengthen the subjective resources among people supporting patients with leukaemia, mainly the sense of 
coherence (sense of intelligibility, resourcefulness and meaningfulness). The following are postulated:

The necessity of providing people supporting leukaemia patients with psychoeducation of coping with stress.

Enabling and popularising the possibility of use of psychological support by people supporting patients with leukaemia.

Creating support groups for people supporting leukaemia patients that allow for the exchange of experience, building a sense of community, as well as releasing difficult emotions.

The authors declare no conflict of interest.

\section{References}

1. de Barbaro B. Between the psychiatric diagnosis and "the family diagnosis". Arch Psych Psychoter 2004; 3: 77-88.

2. Wrona-Polańska H. Zmiany obrazu samego siebie u pacjentów z chorobą białaczkową. Zeszyty Naukowe UJ Prace Psychologiczne 1984; 1: 137-161.

3. Flaskerund JH, Carter PA, Lee P. Distressing emotions in female caregivers of people with AIDS, age-related dementias, and advanced-stage cancers. Perspect Psychiatr Care 2000; 36: 121-130.

4. Wrona-Polańska H. Zdrowie i jego psychobiologiczne mechanizmy. In: Zdrowie - stres - choroba w wymiarze psychologicznym, Wrona-Polańska H (ed.). Impuls, Kraków 2008; 17-37.

5. Plopa M. Psychologia rodziny. Teoria i badania. Wydawnictwo Elbląskiej Uczelni Humanistyczno-Ekonomicznej, Elbląg 2005.

6. de Walden-Gałuszko K. Psychoonkologia w praktyce klinicznej. Wydawnictwo Lekarskie PZWL, Warszawa 2011.

7. Lambley P. Psychologia raka. Jak zapobiegać, jak przeżyć. Książka i Wiedza, Warszawa 1994.

8. Moorey S, Greer S. Cognitive behaviour therapy for people with cancer. Oxford University Press, New York 2003.

9. Nowak-Lipińska K. Wokół psychospołecznych aspektów opieki paliatywnej. In: Zdrowie człowieka i jego edukacja gerontologiczna, Kuchcińska M (ed.). Wydawnictwo Akademii Bydgoskiej im. Kazimierza Wielkiego, Bydgoszcz 2004; 79-86.

10. Beszczyńska B. Molekularne podstawy zaburzeń psychicznych wywołanych stresem. Postepy Hig Med Dosw 2007; 61: 690-701.

11. Epel ES, Blackburn EH, Lin J, Dhabhar FS, Adler NE, Morrow JD, Cawthon RM. Accelerated telomere shortening in response to life stress. Proc Natl Acad Sci U S 2004; 101: 17312-17315.

12. Calado RT, Young SN. Telomere Diseases. N Engl J Med 2009; 361 2353-2365.

13. Lazarus RS, Folkman S. Stress, appraisal and coping. Springer-Verlag, New York 1984; 19.

14. Lazarus RS. Coping theory and research: Past, present and future. Psychosom Med 1993; 55: 234-247.

15. Heszen I. Psychologia stresu. Korzystne i niekorzystne skutki stresu życiowego. PWN, Warszawa 2013.

16. Łosiak W. Psychologia stresu. Oficyna Wydawnicza Łośgraf, Warszawa 2012.

17. Wrona-Polańska H. Zdrowie jako funkcja twórczego radzenia sobie ze stresem. Wydawnictwo Naukowe Akademii Pedagogicznej, Kraków 2003

18. Folkman S, Moskowitz JT. Positive affect and meaning-focused coping during significant psychological stress. In: The scope of social psychology. Theory and application, Hewstone M, Schut HAW, de Wit JBF, et al. (ed.). Psychology Press, New York 2007; 193-208.

19. Folkman S. The case for positive emotions in the stress process Anxiety Stress Coping 2008; 21: 3-14.

20. Jośko J. Pozytywne emocje siłą sprawczą zdrowienia. Probl Hig Epidemiol 2011; 92: 374-376.

21. Fredrickson BL, Tugade MM, Waugh CE, Larkini GR. What good are positive emotions in crises? A prospective study of resilience and emotions following the terrorists attacks on the United States on September 11th, 2001. J Pers Soc Psychol 2003; 84: 365-376.

22. Hobfoll SE. Stres, kultura i społeczność. Psychologia i filozofia stresu. GWP, Gdańsk 2006; 62.

23. Heszen I, Sęk H. Zdrowie i stres. In: Psychologia. Podręcznik akademicki, Strelau J, Doliński D (ed.). GWP, Gdańsk 2008; 701-734.

24. Wrona-Polańska $H$. Twórcze zmaganie się ze stresem szansą na zdrowie. Funkcjonalny Model Zdrowia osób po transplantacji szpiku kostnego. Wydawnictwo Uniwersytetu Jagiellońskiego, Kraków 2011

25. Makowska H, Poprawa R. Radzenie sobie ze stresem w procesie budowania zdrowia. In: Psychologia zdrowia, Dolińska-Zygmunt C (ed.). Wydawnictwo Uniwersytetu Wrocławskiego, Wrocław 1996; 67-100.

26. Bevans M, Sternberg EM. Caregiving burden, stress and health affects among family caregivers of adult cancer patients. JAMA 2012; 307: 398-403

27. Law B. Career management - place, space and social enclaves. Journal of the National Institute of Career Education and Counselling 2013; 31: 3-8.

28. Baran J. Zastosowanie koncepcji stresu traumatycznego w badaniach dzieci z chorobami nowotworowymi i ich rodziców. Psychoonkologia 2009; 1-2: 28-32.

29. Cieciuch J. Nadzieja jako moderator związku poczucia koherencji z preferencjami wartości. Kwartalnik Naukowy 2010; 2: 25-38.

30. Sek H, Ścigała I. Stres i radzenie sobie w modelu salutogenetycznym. In: Człowiek w sytuacji stresu: problemy teoretyczne i metodologiczne, Heszen-Niejodek I, Ratajczak Z (ed.). Wydawnictwo UŚ, Katowice 1996; 133-150.

31. Pasikowski T. Stres i zdrowie. Podejście salutogenetyczne. Wydawnictwo Fundacji Humaniora, Poznań 2000.

32. Williams LA. Whatever it takes: Informal caregiving dynamics in blood and marrow transplantation. Oncol Nurs Forum 2007; 34 : 379-387.

\section{Address for correspondence}

\section{Anna Kaczmarska-Tabor}

Department of Applied Psychology

Institute of Educational Sciences

Pedagogical University of Cracow

4 Ingardena St.

30-060 Cracow, Poland

e-mail: anna.kaczmarska@interia.eu

Submitted: 30.11 .2018

Accepted: 23.04.2019 